
in die proses om die spyskaart van aksies te ontwikkel en te struktureer, en verduidelik hoe om die inligting wat in die Green Book vervat is, te gebruik om die beplanning van veerkragtige nedersettings in Suid-Afrika te bevorder.

\section{Introducing the Green Book: A practical planning tool for adapting South African settlements to climate change}

\section{Willemien van Niekerk, Amy Pieterse \& Alize le Roux}

\author{
DOI: $h$ ttp://dx.doi.org/10.18820/2415-0495/trp77i1.8 \\ Peer reviewed and revised October 2020 \\ Published December 2020 \\ *The authors declared no conflict of interest for this title or article
}

\begin{abstract}
The Green Book is not a book, but a novel, practical online planning tool to support the adaptation of South African settlements to the impacts of climatic changes and severe events. It provides evidence of current and future (2050) climate risks and vulnerability for every local municipality in South Africa (including settlements) in the form of climate-change projections, multidimensional vulnerability indicators, population-growth projections, and climate hazard and impact modelling. Based on this evidence, the Green Book developed a menu of planning-related adaptation actions and offers support in the selection of appropriate actions from this menu to be integrated into local development strategies and plans. The second half of this article describes the steps involved in the process of developing and structuring this menu of actions and explains how the information contained in the Green Book can be used to promote the planning of climate-resilient settlements in South Africa.
\end{abstract}

Keywords: adaptation, Green Book, online planning tool, South Africa

\section{BEKENDSTELLING VAN DIE GREEN BOOK: 'N PRAKTIESE BEPLANNINGSINSTRUMENT OM SUID-AFRIKAANSE NEDERSETTINGS AAN TE PAS VIR KLIMAATSVERANDERING}

Die GreenBookisnie'nboeknie, maar'nnuwe, praktieseaanlyn beplanningsinstrument wat ondersteuning bied om Suid-Afrikaanse nedersettings vir klimaatsverandering en ernstige weersverskynsels aan te pas. Dit verskaf bewyse van huidige en toekomstige (2050) klimaatsrisiko's en kwesbaarheid vir elke plaaslike munisipaliteit in SuidAfrika (insluitend nedersettings) in die vorm van klimaatsveranderingprojeksies, multidimensionele kwesbaarheidaanwysers, bevolkingsgroei-projeksies, en klimaatverskynsels en impak modellering. Gebaseer op hierdie bewyse het die Green Book 'n 'spyskaart' van beplanningverwante aanpassingsaksies ontwikkel, en bied ondersteuning met die keuse van toepaslike aksies om geïntegreer te word in plaaslike ontwikkelingstrategieë en planne. Die tweede helfte van die artikel
Sleutelwoorde: aanlynbeplanningsinstrument, aanpassing, Green Book, Suid-Afrika

\section{PHATLALATSO EA BUKA E TALA (GREEN BOOK): SESEBELISOA SE SEBETSANG SA HO RALA LIBAKA TSA BOLULO TSA AFRIKA BOROA HO IKAMAHANTSOE LE PHETOHO EA MAEMO A LEHOLIMO}

Buka e tala ha se buka fela, empa ke sesebediswa sa thero a litoropo se setja, se sebetsang khokahanyong le inthanete, ho ts'ehetsa tloaetso ea libaka tsa bolulo tsa Afrika Boroa litlamorao tsa liphetoho tsa maemo a leholimo le likoluoa. E fana ka bopaki ba likotsi tse ka tlisoang ke phetoho ea boemo ba leholimo ba hajoale le ba nakong e tlang (2050) le tlokotsi e tobaneng le masepala e mong le e mong oa lehae Afrika Boroa (ho kenyeletsoa le libaka tsa bolulo) ka sebopeho sa likhakanyo tsa phetoho ea maemo a leholimo, lits'oants'o tsa tlokotsi ka ho fapana, likhakanyo tsa kholo ea lipalopalo tsa baahi, le kotsi ea maemo a leholimo 'moho le mehlala ea litlamorao. Ho ipapisitse le bopaki bona, Buka e Tala e hlahisitse lethathamo la liketso tse amanang le thero ea litoropo mme e fana ka ts'ehetso ho khethoeng ha liketso tse nepahetseng ho tsoa lenaneng lena hore li kenngoe maanong le mererong ea nts'etsopele ea lehae. Karolo ea bobeli ea sengoloa sena e hlalosa mehato e amehang molemong oa ho nts'etsapele le ho hlophisa lenane lena la liketso mme e hlalosa hore na thaiso-leseling e ka bukeng ena e ka sebelisoa joang ho ntšetsa pele moralo oa libaka tsa bolulo tse matlafatsang maemo a leholimo Afrika Boroa.

Ms Willemien (C.W.) van Niekerk, Principal Researcher, CSIR Smart Places, P.O. Box 395; Pretoria 0001. Phone: 012 841 2552, email: <wvniekerk@csir.co.za>, ORCID: https://orcid.org/0000-0001-6187-9520.

Ms Amy (A.) Pieterse, Senior Researcher, CSIR Smart Places, P.O. Box 395; Pretoria 0001. Phone: 0128414220 , email: <apieterse@csir.co.za>, ORCID: https://orcid.org/0000-0001-8270-456X.

Ms Alize (A.) le Roux, Principal Researcher, CSIR Smart Places, P.O. Box 395; Pretoria 0001. Phone: 0128413242 , email: <aleroux1@csir.co.za>, ORCID: https://orcid.org/0000-0002-9214-5076. 


\section{INTRODUCTION}

A 2019 study by the Council for Scientific and Industrial Research (CSIR) projects that the total South African population will grow by an additional 19 to 24 million between 2011 and 2050, totalling between 58 and 62 million people. The biggest population growth will be in the country's towns and cities (Le Roux, Arnold, Makhanya \& Mans, 2019a: online). These places are already and will continue to be impacted by global climatic changes as well as local extreme weather events such as intense rainfall that causes flooding (Engelbrecht, Le Roux, Arnold \& Malherbe, 2019: online). The combination of population growth (in some towns doubling in the next three decades), an increase in the frequency and intensity of extreme climate-related events, the socio-economic vulnerability of South African communities, and exposure of towns and cities to natural hazards, due to poor planning, will increase the risk for natural disasters to occur, and place tremendous pressure on local municipalities (see Figure 1). To reduce the risk of loss of lives and livelihoods, severe injury, and damage to, or destruction of infrastructure and buildings, all at great cost to society, local municipalities need to adapt now to the current and likely future impacts of climate change.

The Green Book is not a hard copy book, but an interdisciplinary, openaccess, online tool that was developed to support local municipalities in South Africa to adapt settlements to the likely current and future impacts of climate change (CSIR, 2019: online). It is structured into three main components:

i. A series of interactive national story maps that communicate the research methodology and key findings from the research, supported by maps, images and statistics.

ii. A municipal Risk Profile Tool that combines scientific evidence produced from multiple domainspecific research into interactive, composite profiles covering current and future (2050) climate

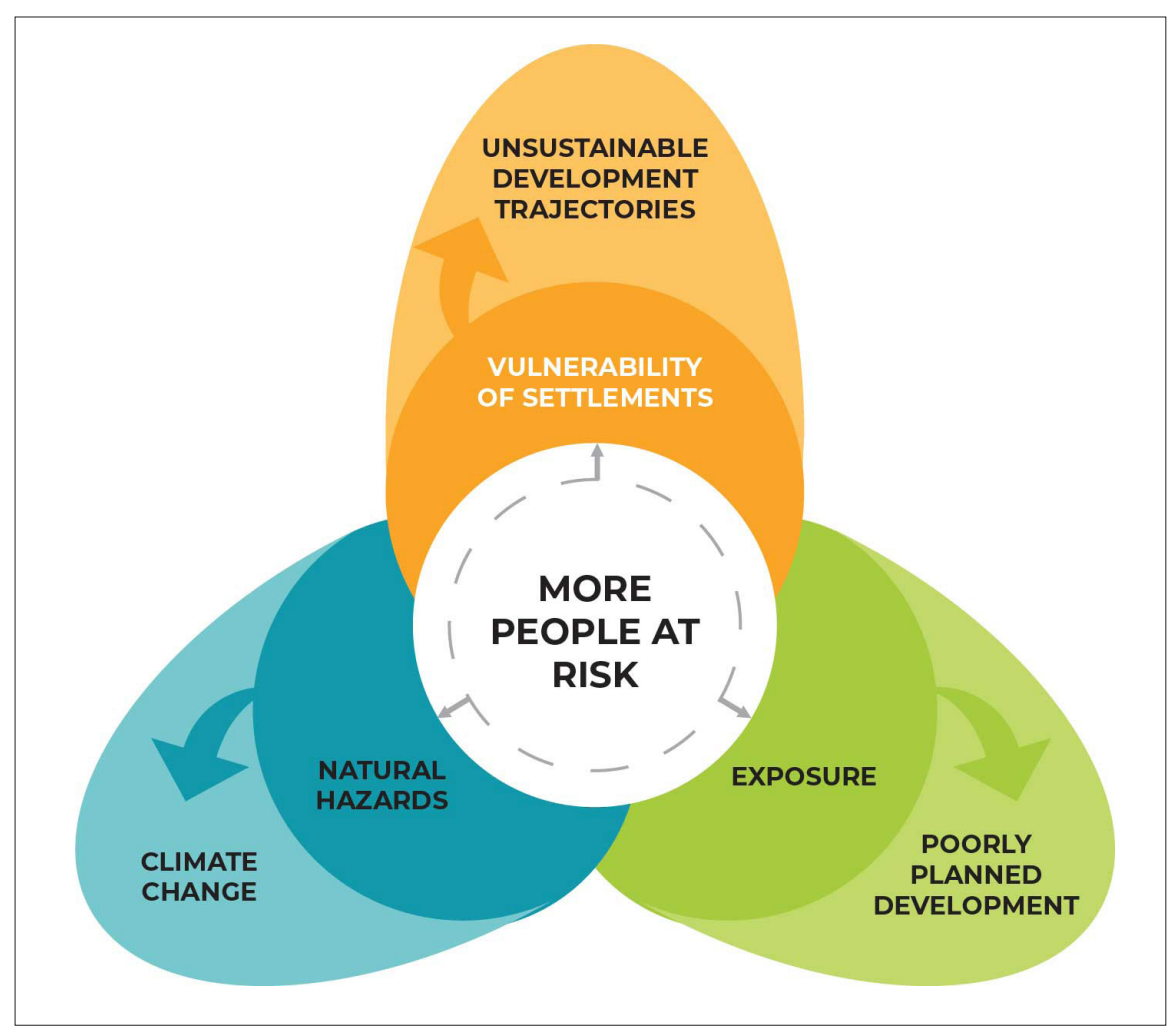

Figure 1: The combination of a hazard, exposure and vulnerability determine the number of people at risk of disaster

Source: Le Roux et al., 2019a: online

risks, impacts and vulnerabilities for all municipalities in South Africa and their settlements.

iii. A municipal Adaptation Actions Tool to support adaptation planning in local municipalities by providing a range of planning and design actions for municipalities that can be integrated into existing planning instruments to adapt their settlements to the likely impacts of climate change, to climate proof their settlements, and to reduce their exposure and vulnerability to hazards and thus the risk of disaster.

This article introduces this freely available, practical, online planning support tool to the planning profession - for which it was specifically developed. The article provides the South African context to urban climatechange risks and vulnerabilities, which is based on new research by the CSIR. It also describes the steps involved in the process of developing and structuring a unique menu of adaptation actions to support local municipalities in South Africa, with integrating climate-change adaptation into the planning of human settlements. Lastly, it explains how the information available in the tool can be applied to support the planning of climateresilient settlements in South Africa.

\section{URBAN CLIMATE- CHANGE RISKS AND VULNERABILITIES IN SOUTH AFRICA}

Local governments are most sensitive to climate risks and vulnerabilities and have thus a distinct role to play in adapting to climate change. It is widely recognised that climate change is felt in cities and towns through both short-term events such as natural disasters and long-term impacts such as rise in temperature (Anguelovski, Chu \& Carmin, 2014: 156-157; Chen, Doherty, Coffee, Wong \& Hellmann, 2016: 403-404). 


\subsection{The impacts of climate change on South African cities by 2050}

The highest resolution $\left(8 \times 8 \mathrm{~km}^{2}\right)$ climate-change projections for South Africa to date were developed by the CSIR and published online in the Green Book (Engelbrecht et al., 2019: online). According to these and other long-standing projections, annual average temperature over the interior of South Africa is projected to rise at roughly one-and-a-half to twice the global rate. The projections indicate that, under a low mitigation scenario (RCP 8.5), temperature increases between $1^{\circ} \mathrm{C}$ and $2.5^{\circ} \mathrm{C}$ may occur over the southern coastal regions by 2050 , while more than $3^{\circ} \mathrm{C}$ is likely over the interior and northern parts of the country. This will very likely instigate a drastic increase in the number of very hot days, ${ }^{1}$ heatwave days,${ }^{2}$ and high fire-danger days. ${ }^{3}$ Projected rainfall patterns over South Africa are more uncertain than projected changes in temperature. A general decrease in rainfall is very likely to occur over southern Africa. More specifically, rainfall is projected to increase over the central interior and east coast of South Africa by 2050 , while the western interior, north-eastern parts and winter rainfall region of the south-western Cape are projected to become generally drier. The frequency of extreme rainfall events ${ }^{4}$ is likely to increase over most of the central interior and east coast of South Africa by 2050 . Extreme rainfall events are mostly caused by intense thunderstorms, often accompanied by lightning, hail, damaging winds, and flash floods (Engelbrecht et al.,

1 Very hot days are days when the maximum temperature exceeds $35^{\circ} \mathrm{C}$ (Engelbrecht et al., 2019: online).

2 The World Meteorological Organization defines a heatwave as five or more consecutive days during which the daily maximum temperature surpasses the average maximum temperature by $5^{\circ} \mathrm{C}$ or more.

3 Fire-danger days are described as days where the McArthur fire-danger index exceeds a value of 24 (Forsyth et al., 2019: online).

4 An extreme rainfall event is defined as $20 \mathrm{~mm}$ of rain occurring within 24 hours over an area of $64 \mathrm{~km}^{2}$ (Le Maitre et al., 2019: online).
2019: online). ${ }^{5}$ Furthermore, sea levels are expected to rise by 0.35 metres to 1 metre by 2100 . Combined with increased storm surges, erosion, urbanisation and disturbances of the environment, this will lead to flooding of low-lying coastal areas if no protective measures are in place (Lück-Vogel, Le Roux \& Ludick, 2019: online). Climate change, specifically an increase in the periods of hot, dry and windy conditions, is likely to increase the frequency of wildfires on the wildlandurban interface of South African settlements (e.g. the Knysna fires of 2017). The high fire-danger periods will increase, particularly in the southern and eastern parts of the country. The projections show a southward and eastward expansion of the occurrence of more than 25 high fire-danger days per year. The most marked shifts in the future are projected to be in the Free State, Western Cape, Eastern Cape, North West and Limpopo provinces (Forsyth, Le Maitre, Le Roux \& Ludick, 2019: online). In terms of recurring drought events, large parts of the country are projected to become drier corresponding to the increase in maximum temperature and very hot days (Beraki, Le Roux \& Ludick, 2019: online).

Figures 2 to 6 show the increase in the risk of these climate-related hazards for South African settlements. It is expected that extreme heat will increasingly be a major hazard for settlements to deal with in the future. Dense and built-up urban spaces absorb heat and can cause heat stress for people and structures, leading to health risks, higher mortality rates, lower quality of life, higher energy use, and economic losses (Engelbrecht et al., 2019: online). The fire danger is also likely to increase under hotter and drier conditions. Furthermore, local municipalities will have to plan for both drought conditions, as well as extreme rainfall events and coastal storm surges that cause flooding. Ensuring water and food security will become more urgent as the country

5 For more information on climate change projections and impacts on settlements, see the technical reports under the resources page on the Green Book website <https:// www.greenbook.co.za/resources.html> becomes drier, while simultaneously settlements will need more protection from flooding (Le Maitre, Kotzee, Le Roux \& Ludick, 2019; Beraki et al., 2019; Forsyth et al., 2019: online). Flooding and fires can cause huge damage to, and destruction of buildings and infrastructure, high repair and maintenance costs, disruption of services, and hamper economic growth.

\subsection{The vulnerability of South African settlements to climate-related events}

Between 1980 and 2019, South Africa experienced over 82 hydrometeorological hazards (floods, storms, landslides, wildfires, droughts, and extreme temperatures) that have resulted in the death of 1,692 people, affected more than 21 million people, and in billions of Rands in direct and indirect losses (Le Roux, Van Huyssteen, Arnold \& Ludick, 2019b: online). It is very likely that hydrometeorological hazards will become more frequent and intense in the future. Local government, in particular, is increasingly faced with the responsibility to address the effects of climate change as their vulnerable communities and infrastructure are affected by climate change-related events (Pieterse, Du Toit \& Van Niekerk, 2020: 2; Pasquini \& Shearing, 2014: 272; Van Niekerk, 2013: 2-3). Combined with a growing urban population and many other local factors, the result is an increase in the overall levels of disaster risk in local municipalities to the extent that finances are being diverted from development planning to disaster response (Van Niekerk \& Le Roux, 2017: 107).

The CSIR projects that, by 2050 , 162 settlements in the country will experience extreme increases in population growth pressure (Figure 7); 263 settlements will experience high increases in population growth pressure (including five of the metropolitan cities); 520 settlements will experience medium growth pressure; 192 settlements will experience a decline in population growth, and 498 settlements will see no or hardly any change in their population growth (Le Roux et al., 2019a: online). 


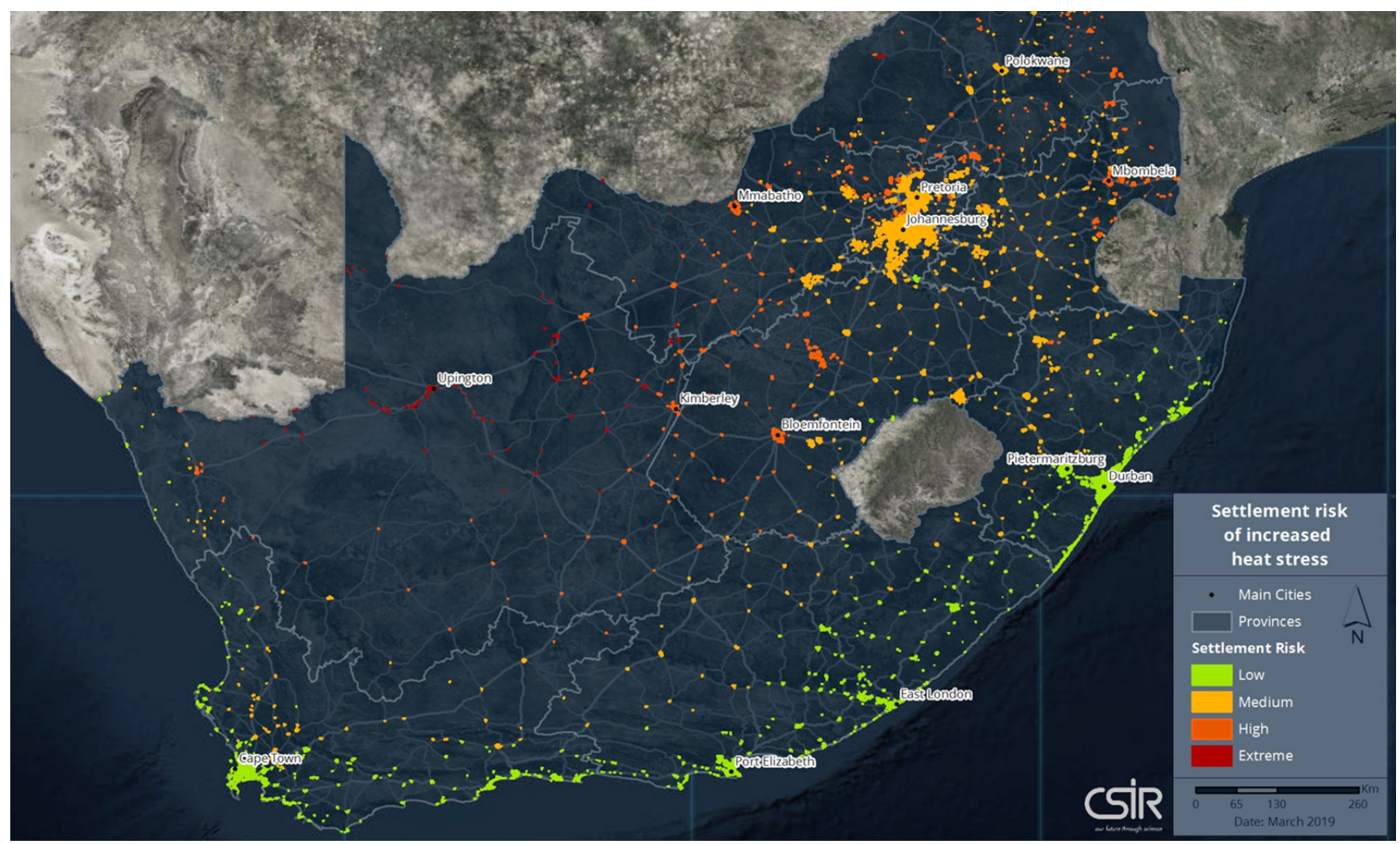

Figure 2: The risk of heat stress for South African settlements by 2050

Source: Engelbrecht et al., 2019: online

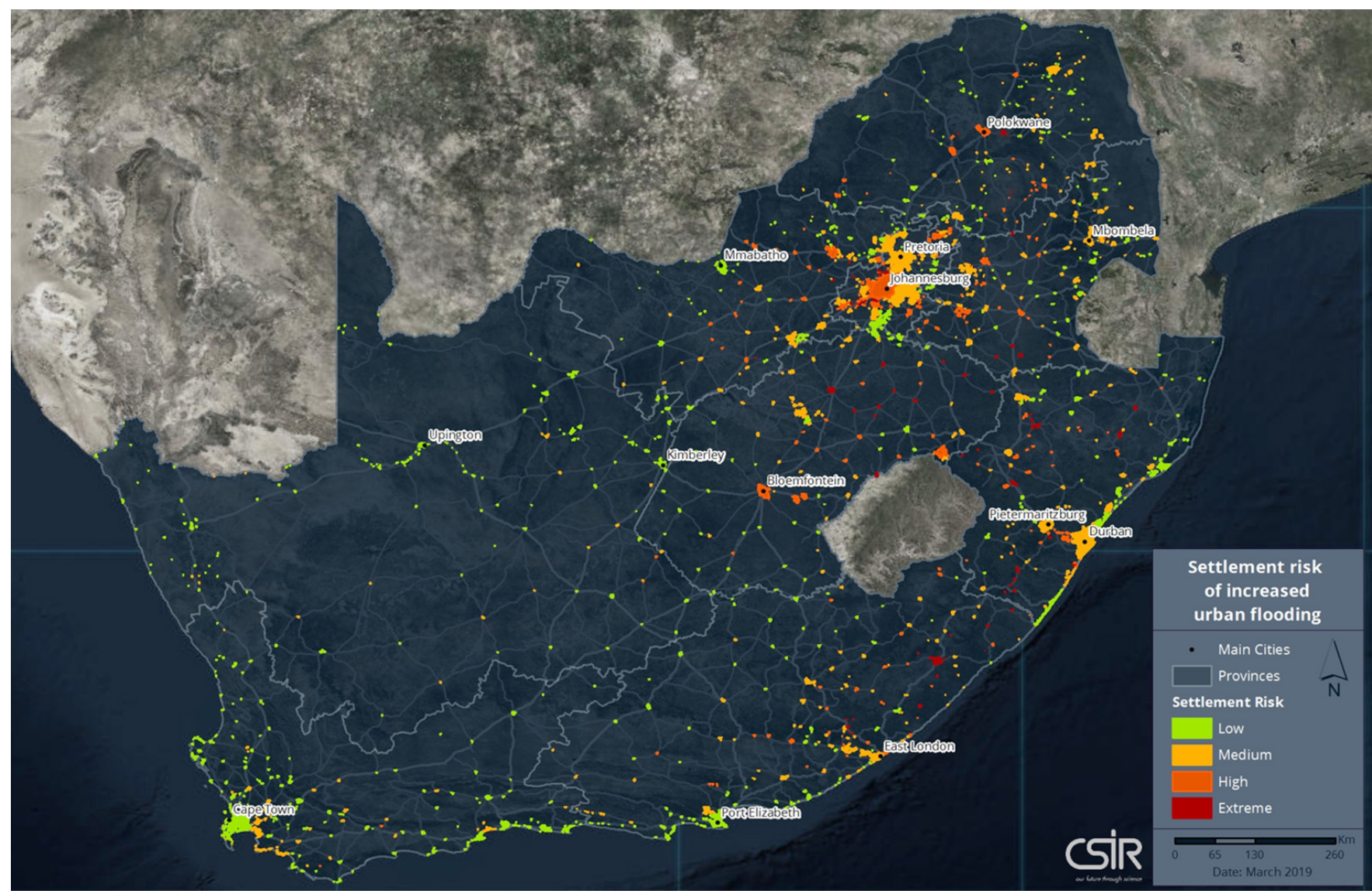

Figure 3: The risk of urban flooding in South African settlements by 2050

Source: Le Maitre et al., 2019: online 


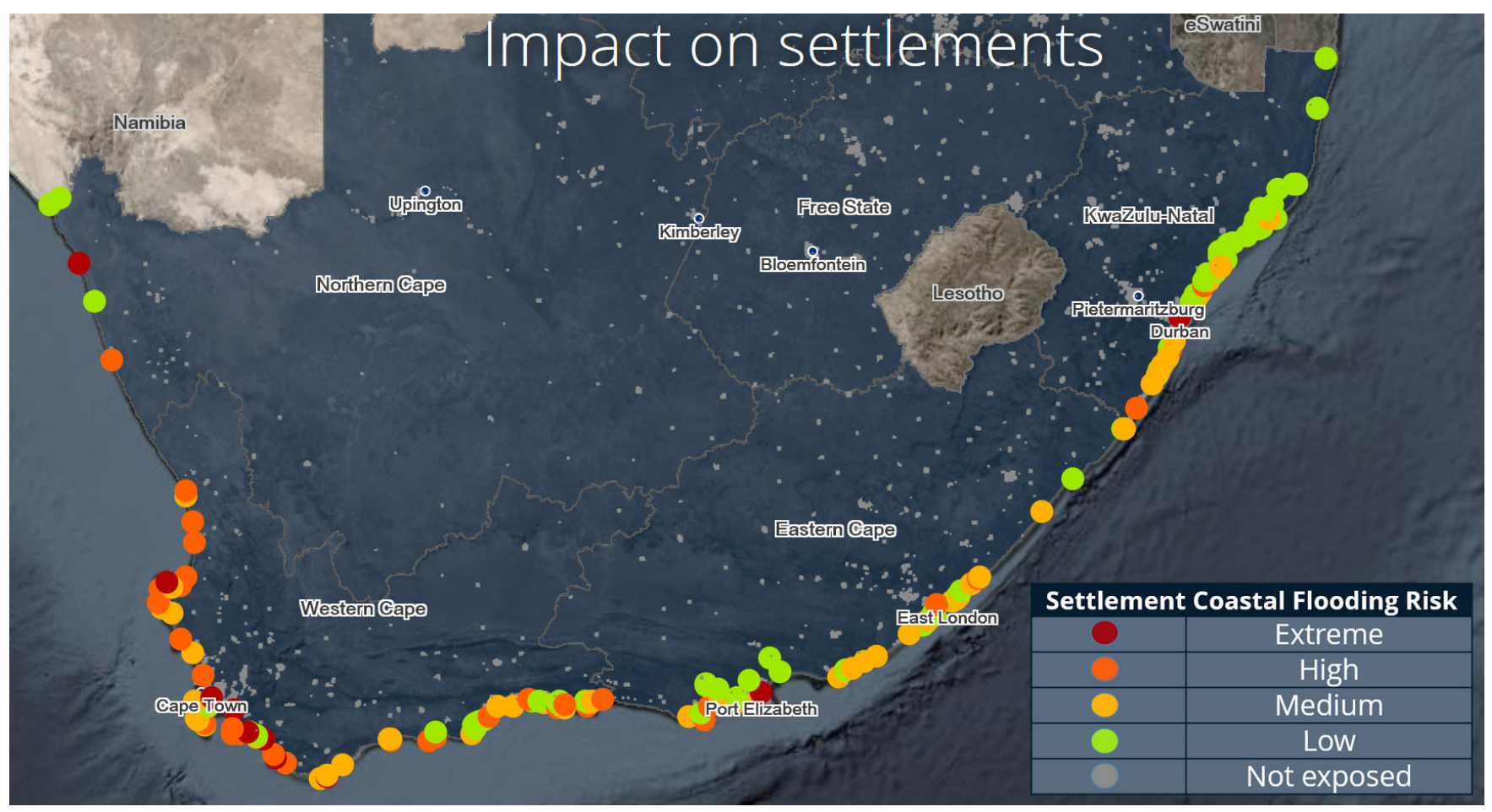

Figure 4: The risk of coastal flooding in South African settlements by 2050

Source: Lück-Vogel et al., 2019: online

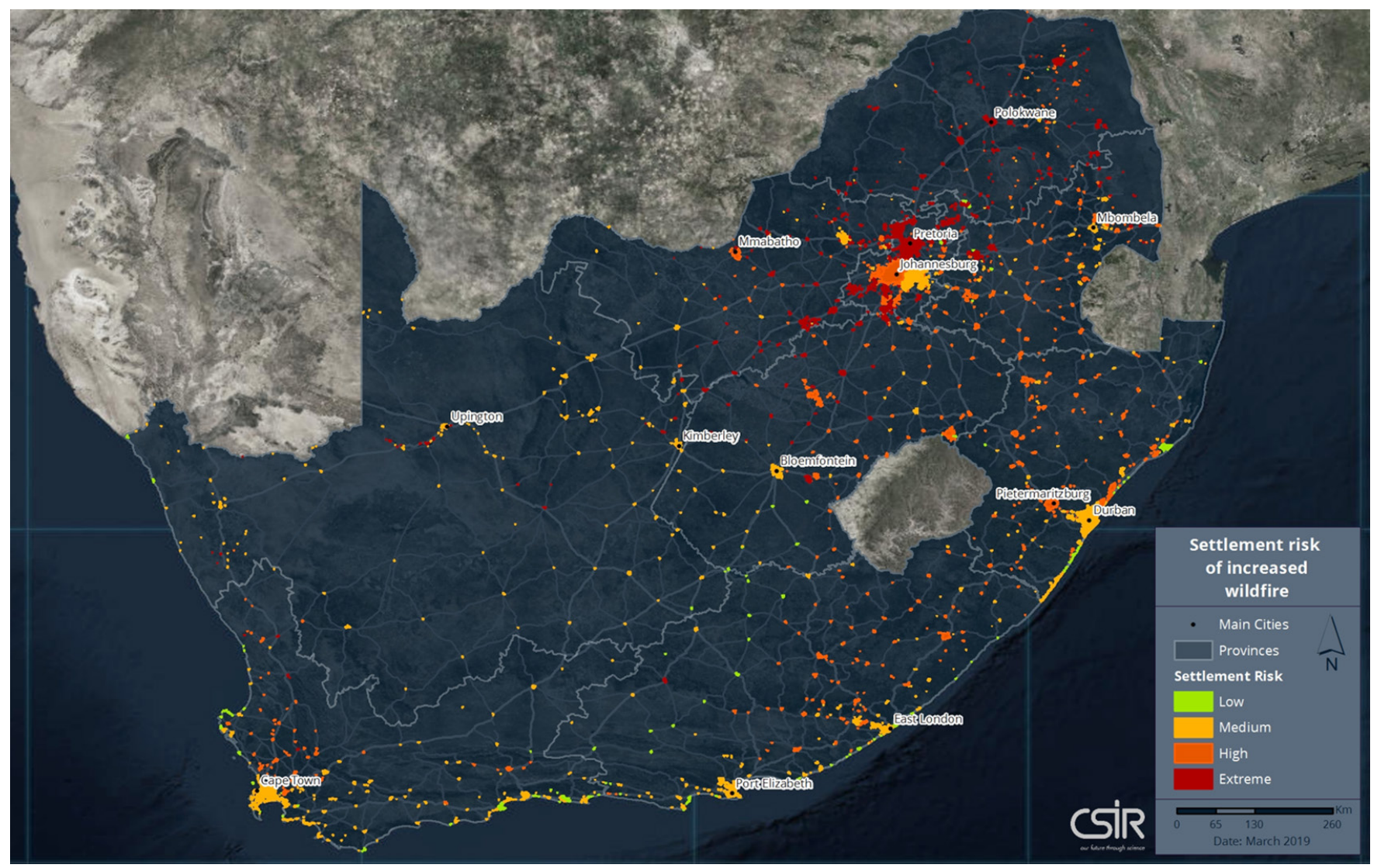

Figure 5: The risk of settlement wildfire in South Africa by 2050

Source: Forsyth et al., 2019: online 


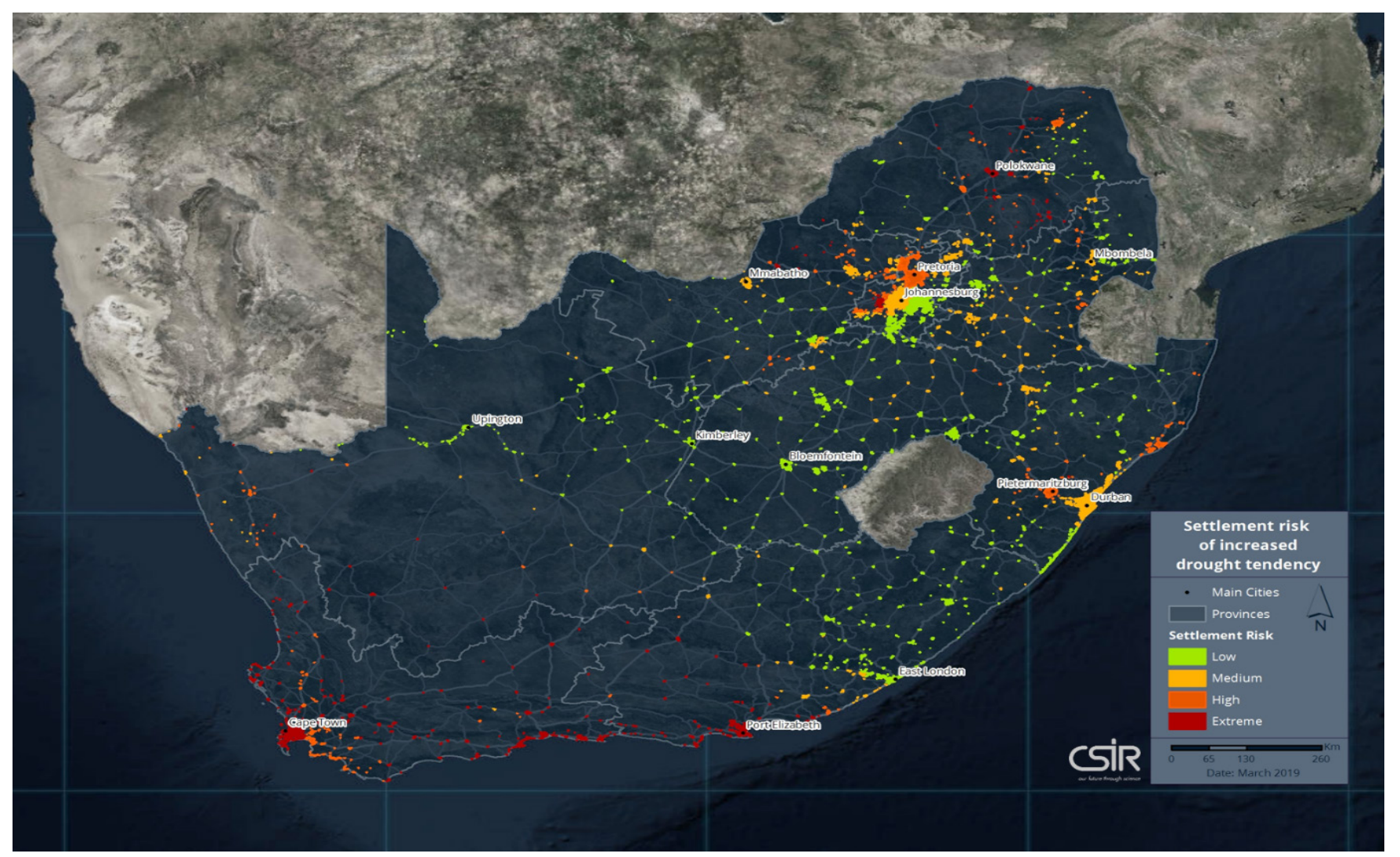

Figure 6: South African settlements at risk of an increase in drought tendency by 2050

Source: Beraki et al., 2019: online

Population growth pressure is the pressure a local government experiences from the rate at which the population is growing and its associated challenges, for example on housing provision and service delivery, and is a combination of the actual and relative population changes between 2011 and 2050 (authors' definition).

The importance of profiling and monitoring the vulnerability of towns and cities, so as to address the resilience of human settlements, is highlighted as an international and national priority in the Sendai Framework for Disaster Risk Management 2015-2030, the New Urban Agenda, the Sustainable Development Goals, the South African Disaster Management Amendment Act, Act No. 16 of 2015, and the National Climate Change Response Policy of 2011 (Le Roux et al., 2019b: online). Vulnerability profiling is complex and often contentious. In the Green Book, the CSIR made a novel attempt to develop an indicator framework that profiles the multiple dimensions of the vulnerability of neighbourhoods, settlements, and municipalities in South Africa, including the inherent vulnerability of people, infrastructure, services, economic activities, and natural resources. To mention but two national examples. According to the socio-economic vulnerability assessment (Figure 8), the Eastern Cape and KwaZulu-Natal provinces have the largest number of socioeconomic vulnerable municipalities in the country (based on 2011 data). Municipalities in the north of the North West, Northern Cape and Free State provinces are also socio-economically vulnerable (Le Roux et al., 2019b: online).

According to the economic vulnerability assessment (Figure 9), the largest number of economically vulnerable municipalities in the country is found in the North West province, followed closely by Limpopo and Mpumalanga, with the single most vulnerable municipalities located in Limpopo (Le Roux et al., 2019b: online).
This type of risk and vulnerability information is available per municipality in the Green Book. The Green Book has the ability to dynamically and interactively generate risk and vulnerability profiles for all 213 municipalities and 1,637 settlements in South Africa. Most of this information is quantified. By typing in the name of a municipality in the Green Book Risk Profile Tool (Le Roux et al., 2019c: online), it interactively integrates information per municipality (and their respective settlements) on the current vulnerability, future population growth pressure, climate-change projections for temperature, rainfall, extreme rainfall and very hot days for 2050, the current and future impact of climate change on key resources such as water availability, the economy and agricultural production (also as proxy for food security), and the increase in the risk of climate-related hazards for local municipalities in 2050 (Le Roux, Van Niekerk, Arnold, Pieterse, Ludick, Forsyth, Le Maitre, Lötter, Du Plessis \& Mans, 2019c: online). 


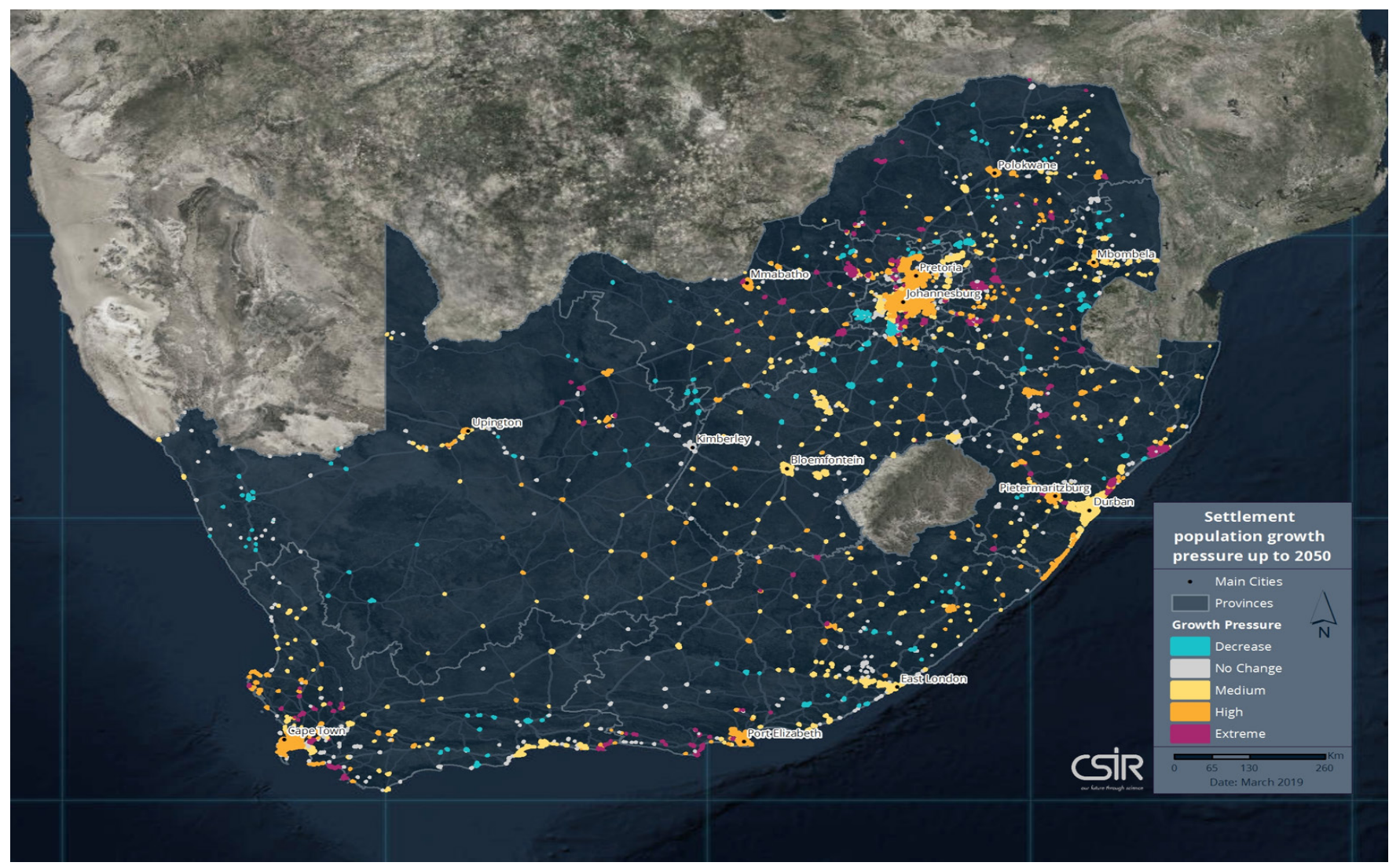

Figure 7: The population growth pressure of South African settlements Source: Le Roux et al., 2019a: online

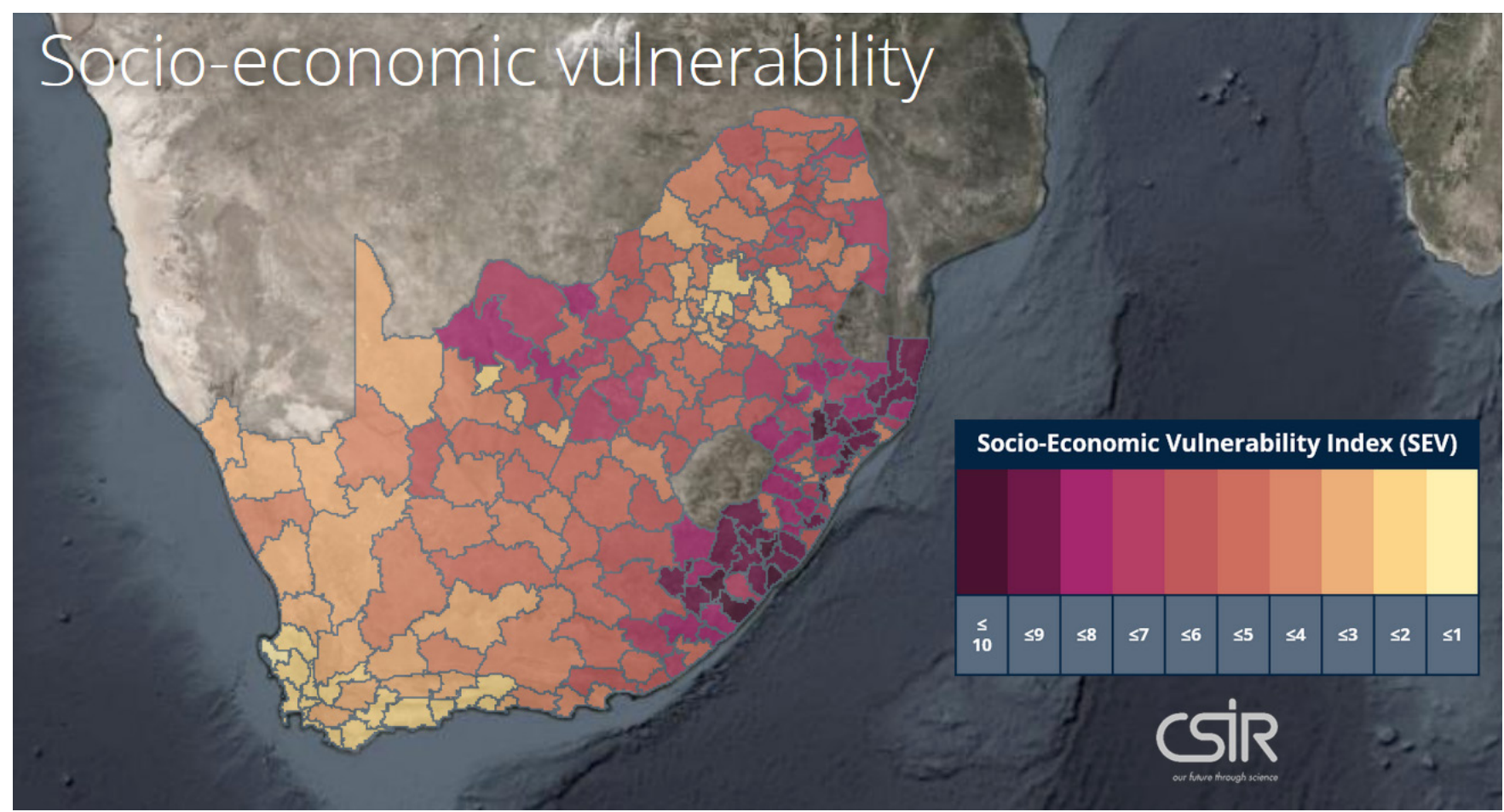

Figure 8: The socio-economic vulnerability of South African settlements based on 2011 data Source: $\quad$ Le Roux et al., 2019b: online 


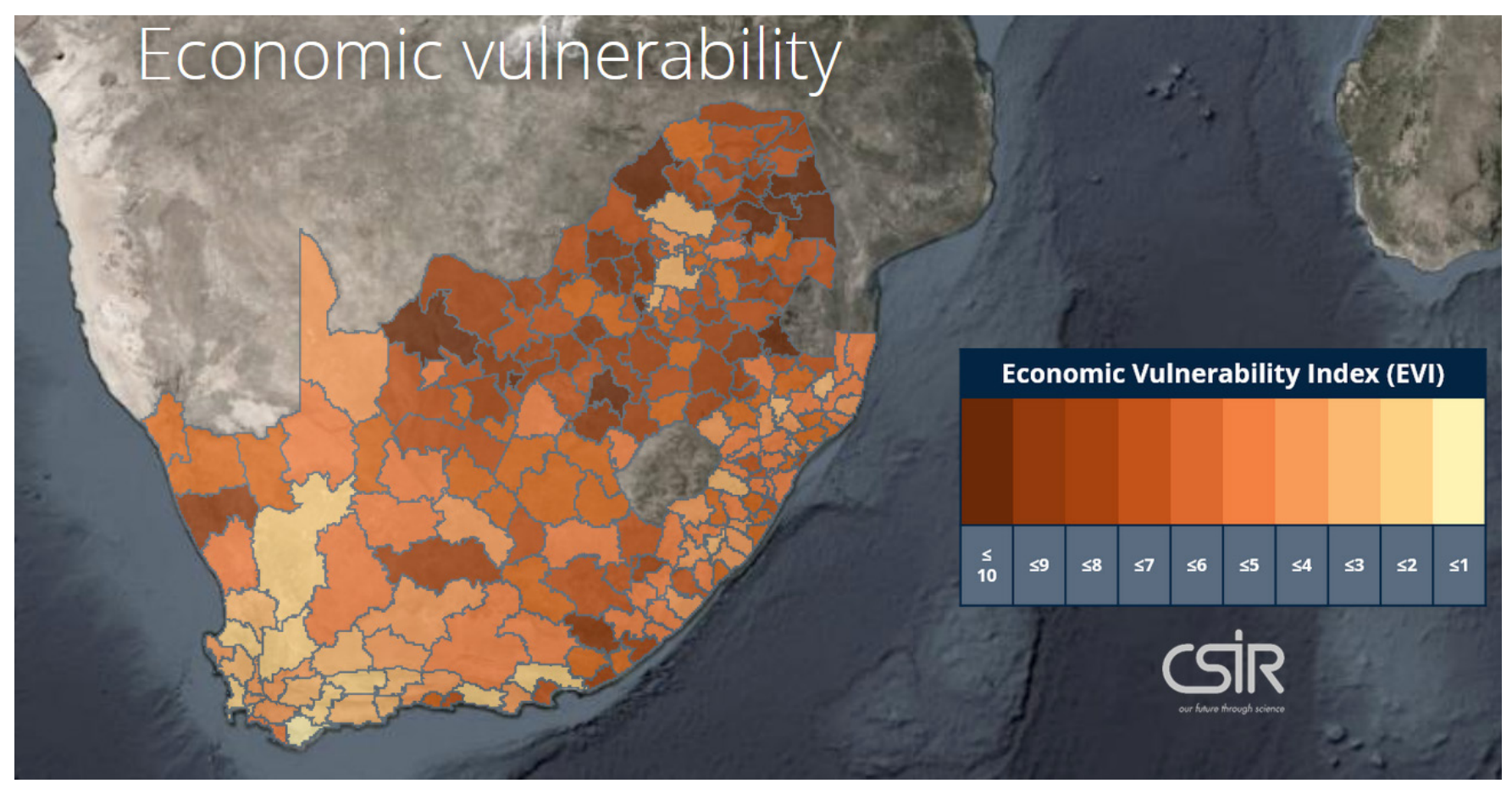

Figure 9: The economic vulnerability of South African settlements based on 2011 data

Source: Le Roux et al., 2019b: online

The municipal Risk Profiling Tool replaces the time-consuming and labour, data and analytically intensive way in which risk assessments were carried out previously, and is an invaluable tool in the disaster risk and vulnerability space nationally. Many of the frameworks, concepts, indicators, tools, data sets and models that were required to accomplish the Green Book project objectives were not readily available and had to be developed and/or significantly enhanced for this purpose.

Having access to this risk and vulnerability information supports local municipalities in the planning of climate-resilient cities, by providing the evidence for climate-response strategies, spatial development frameworks, and the prioritisation of adaptation actions in other sectoral plans. The next sections show how this information was used to develop adaptation actions relevant to the local planning function in South Africa, and how the actions can be used to adapt settlements to become more resilient to the current and likely future climatic changes and severe events.

\section{ADAPTING SOUTH AFRICAN SETTLEMENTS TO BECOME CLIMATE RESILIENT}

\subsection{Conceptual framework}

To leverage the imperative as well as the opportunity to respond to the impacts of climate change on the local level, the approach to and management of risk and vulnerabilities need to change. Urban planning, as a policy instrument that can address both the causes and the impacts of climate change, is a key component of such change (Hagen, 2016: 14). Transformational adaptation has emerged as a concept in response to the perception that incremental adaptation does not suffice to bring about the change needed to secure a sustainable and resilient future and has been used within the climate-change adaptation research community for close to a decade (Kates, Travis \& Wilbanks, 2012: 7156-7157; Lonsdale,

Pringle \& Turner, 2015: 10; Pelling, O'Brien \& Matyas, 2015: 113-115). The Intergovernmental Panel on Climate Change (IPCC) took up the term in their reporting, and defines transformational adaptation as involving new approaches to urban planning and systemic change, while incremental adaptation is only about responding and preparing for the impacts of climate change (IPCC, 2018: 7). Pelling et al. (2015: 114) describe transformational adaptation as the ability to adjust existing systems to follow alternative development pathways. They argue that transformational adaptation addresses the structural causes of vulnerability as opposed to incremental adaptation that addresses the proximate causes. The concept of transformational adaptation highlights the important link between adaptation and development, and that adaptation needs to be integrated or mainstreamed into local planning. Integrating climate-change adaptation into planning limits policy duplications and contradictions, allows early action that is more cost effective than after-the-fact response, and facilitates transformational adaptation (Wilson, 2006: 611; Rauken, Mydske \& Winsvold, 2015: 409-410; Pelling et al., 2015: 114). The development 
of the Adaptation Actions Tool in the Green Book promotes the integration of adaptation actions that would transform urban spaces.

\subsection{Adaptation is a local planning issue}

South African municipalities are required to plan for the future, while simultaneously dealing with the day-to-day management and development of the town or city in the face of fiscal, information, and capacity constraints. These challenges become even more daunting when threatened by the immediate and long-term impacts of climate change that give rise to the number of people affected by natural disasters. The potential risks can be addressed through effective planning and interventions, i.e. climatechange adaptation, that reduce the exposure and vulnerabilities of municipalities, and strengthen their ability to cope with potential hazards (Le Roux et al., 2019b: online).

Climate-change adaptation is the process of adjustment to actual or expected climate and its effects. Adaptation seeks to moderate or avoid harm and exploit beneficial opportunities (IPCC, 2014: 76). As the level of governance closest to the people, local government adaptation is critical to attend to vulnerable spaces and communities (Pieterse, Van Niekerk \& Du Toit, 2018: 15). Since climate change is a cross-cutting issue, it can be most effectively addressed when adaptation is integrated with existing local spatial planning processes and instruments. There are existing linkages and overlaps between climate-change adaptation and local planning that can potentially facilitate the creation of resilient settlements in South Africa (Pieterse et al., 2018: 21). However, since adaptation is often one of a multitude of long-term context-dependent dilemmas that require urgent attention by the planning profession, it is often of a less immediate concern (Pieterse, Van Huyssteen, Van Niekerk, Le Roux, Napier, Ndaba \& Mahlelela, 2016: 111).
Integrating climate adaptation in development plans and processes ensures that hard-won development gains are not undermined and that future interventions contribute to resilient settlements in light of a changing climate. This approach is likely to be more successful than addressing adaptation in isolation through a sectoral climate-change policy or plan.

The potentially beneficial interrelationship between climatechange adaptation, spatial planning and land-use management practices are, first, that spatial planning and land-use management can provide strategic and implementation instruments to enable integrative and coordinated place-specific climate-change adaptation (Faling, 2010) at the most appropriate level (Biesbroek, Swart \& Van der Knaap, 2009: 231). Secondly, it is acknowledged that contemporary spatial planning focuses on ensuring sustainable development, and adaptation strategies can potentially form part of this drive. Some adaptation measures are not necessarily novel but may be similar to existing sound planning practices that foster sustainable and resilient human settlements and urbanisation. In the face of climate change, planning measures or land-use guidelines may need to be reiterated, reinforced, adapted or subjected to more stringent enforcement or control measures.

The Green Book project developed an adaptation planning support tool to assist role players (specifically local government) involved in the adaptation of settlements with the selection of adaptation actions to be mainstreamed into local development plans and strategies. The ultimate goal of the tool is to raise awareness, preparedness, and resilience to extreme weather events by adapting to incremental climate change, reducing future risks, and exploiting opportunities for sustainable and transformational development (Pieterse, Davis-Reddy \& Van Niekerk, 2019b: 4). The remainder of this article describes how the content of the Adaptation Actions Tool was developed, what the tool looks like, and how it can be used to support the planning of resilient South African settlements.

\subsection{Method for developing the Adaptation Actions Tool}

The online Adaptation Actions Tool was developed through the use of a mixed-methods research approach that utilised a qualitative, iterative and explorative research approach to develop the menu of adaptation actions into an online planning support tool. No known technology existed that could be harnessed for utilisation; thus, the development of a new online open-access system was needed. This was done using current, appropriate and newly established software development and website development technology. Particular attention was paid to the users' experience by designing a graphical user interface that captured the attention of local and municipal planners. This article focuses on the method that was followed to develop the content of the Adaptation Actions Tool.

The Adaptation Actions Tool (Van Niekerk et al., 2019) is an interactive typology of appropriate, local, mutually supportive settlement planning and design actions. It proposes a basket of mutually reinforcing actions that are linked to each other so that no action is loose standing, but is supported. The tool was developed to propose adaptation actions to reduce the exposure of vulnerable people and places to the climate risks identified in the Risk Profile Tool of the Green Book. Thus, based on the specific risk and vulnerability profile of a local municipality, explicit actions can be selected to be integrated into the planning of human settlements. The aim of the Adaptation Actions Tool is to

i. avoid or minimise the expected impacts of climate hazards;

ii. restore, maintain and transform systems to be more resilient to future changes, or 
iii. retrofit infrastructure to reduce future impact or loss (Van Niekerk, Pieterse, Davis-Reddy, Le Roux \& Lötter, 2019: online). The typology of actions is accompanied by a guideline that provides a roadmap for implementation by municipalities.

The following steps recount the process of developing the content of this planning support tool.

\subsubsection{Developing a shared understanding and selection criteria}

Climate-change adaptation is a wide field, and cuts across numerous sectors and disciplines. Twenty researchers and as many peer reviewers were involved in the development and review of the typology. Experts included engineers, architects, urban planners, anthropologists, a microbiologist, environmental scientists, an integrated waste specialist, and geographers. It was thus necessary to develop a shared understanding between all the domain-specific experts to clarify the role of the researchers, who the target audience was, climate-change adaptation and urban planning-related terminology, and which likely future climate-related hazards needed to be addressed by the adaptation actions. It was also necessary to develop criteria for the selection of the adaptation actions, namely the range, scale, and nature of the adaptation actions that were to be considered for inclusion in the typology. The process and parameters were tested with the research team as well as with a reference group consisting of individuals in the climate-change adaptation field.

This shared understanding entailed the following:

- Task: To review adaptation literature and make recommendations as to which adaptation actions to include in this South African typology.

- Target audience: People involved in the planning of human settlements at a municipal level, including spatial planning, landuse management, infrastructure planning, settlement design, environmental planning, climate-change adaptation, disaster risk reduction, and engineering services.

- Terminology: Clarification on what is meant by adaptation, adaptation actions, disaster risk reduction, mitigation, urban planning, and human settlements.

- $\quad$ Priority hazards: The Green Book Risk Profile Tool identified the biggest climate-related threats to South African settlements as inland flooding, drought, wildfire, and coastal flooding (Le Roux et al., 2019c: online). Extreme heat was also identified as a climate hazard under the climate-change projections (Engelbrecht et al., 2019: online).

The selection criteria used to screen the literature were:

- Adaptation actions need to be linked to the mandate of local government, as set out in Schedules 4 and 5 of the Republic of South Africa Constitution, 1996.

- Adaptation actions have to be suitable for urban and built-up areas.

- Adaptation actions have to apply to the local planning function.

- Adaptation actions need to support good planning principles, as set out in the Spatial Planning and Land Use Management Act, 2013.

- Adaptation actions need to support climate-change mitigation, where appropriate.

- Adaptation actions need to provide an economic, social or environmental benefit regardless of climate change.

\subsubsection{Reviewing literature}

Once a shared understanding was reached, which took a surprisingly long time, the second step in developing the typology was to identify and review relevant journal articles, reports and adaptation plans and strategies (local and others) to identify those climate-change adaptation actions that met the parameters of the study. For each sector or theme, various climatechange adaptation actions and measures relevant to settlement planning and design were reviewed. Many of the themes such as gender equity and water-sensitive urban design cut across sectors and some duplication occurred, which were eliminated in the consolidation step. For each adaptation action, a table was completed with a description of the action, including the constraints and benefits. Each action was also associated with an urban planning function, local or international examples, one or more climate hazards, and an adaptation strategy (see definitions below). Key end-users of adaptation plans in municipalities as well as project champions and experts in the public, private and non-governmental organisation (NGO) sectors were consulted to complement the desktop analysis.

\subsubsection{Peer review}

The critical role of local government as well as the importance of other role players, including communitybased organisations, civil society organisations, as well as science and research organisations in adaptation planning are recognised (Parnell, 2016: 529-539). The value of place-based governance, multistakeholder and intergovernmental collaboration (Carmona, Burgess \& Badenhorst, 2009; Pieterse et al., 2016: 117) is also acknowledged in the planning and implementation of adaptation measures. Thus, the actions were peer reviewed and refined through an iterative process and informed by expert local knowledge and examples.

\subsubsection{Consolidating the range of actions}

In the next step, the range of adaptation actions was consolidated in one database in the form of a menu of adaptation actions. Even though a shared understanding and selection criteria were established at the outset, the wide variety and differences in the scale and quality 
of the output posed some challenges to the core adaptations team when consolidating the actions. The biggest challenges were that many adaptation actions were not on a local municipal scale, were not related to the urban planning function, and were not complete in their descriptions. The core adaptations team revisited the selection criteria and determined that, in order to fulfil the goal of the project, namely the adaptation of settlements, and to focus on the target audience, the following categories of actions were included, namely spatial planning, land-use management, landscape and urban design, infrastructure and engineering service provision, and environmental planning. It was decided not to include actions at a site level, namely in the fields of housing, site design, building design, and building regulations. The core adaptations team then applied the expanded selection criteria to select the appropriate actions. The list of adaptation actions was then tested during a focus group with officials from the City of Cape Town. This consultative process identified and addressed key gaps. A final selection of adaptation actions was made, and this constituted the menu or list of 81 adaptation actions used for the Adaptation Actions Tool. The menu of actions is relevant to town, city, neighbourhood, or precinct scale and it can even be site specific, as it relates to land use and development control and aspects with possible cumulative settlement-wide impacts.

\subsubsection{Developing an online, interactive typology of actions}

The menu was fairly long and needed further refinement to be structured in a way that one can search and filter for actions in specific categories in an online, interactive platform. A typology of actions was created by distinguishing between three categories, namely the local planning function, climate-change hazard and impacts, and climate-change adaptation strategy. Thus, in the online Adaptation Actions Tool, one can search, select and filter actions in these categories, i.e. one can search for actions that fall within the spatial planning category, address a specific hazard such as urban heat, and fall within a certain adaptation strategy such as a win-win strategy (see Figure 9). As stated earlier, the local planning function was defined to include spatial planning, land-use management, landscape and urban design, infrastructure and engineering service provision, and environmental planning. This category is mutually exclusive; therefore, an action will only fall into one planning function. This classification provides support in identifying in which key plans and instruments the adaptation actions need to be integrated. Priority climate risks were identified as wildfires, inland flooding, coastal flooding, heat stress, drought, and extreme wind speed. Adaptation actions also speak to the impact of climate change on key resources such as groundwater and surface-water depletion, and biodiversity loss. The attributes within this category intersect, meaning that more than one can apply to an individual adaptation action. For example, the action of clearing invasive alien plant species responds to drought, groundwater depletion and surfacewater depletion. Adaptation actions have costs and implications, as well as benefits and co-benefits. The third category considered these attributes and classified the actions according to three strategies:

- Win-win: Adaptive measures that minimise harmful climate impacts and also have other social, economic and environmental policy benefits, including those relating to mitigation.

- No-regrets: Adaptive measures that are justified under all plausible climate futures (including the absence of manmade climate change). The costs of these measures are relatively low. No-regret actions are often appropriate in the near-term.

- Low-regrets: Adaptive measures for which the associated costs are relatively low and for which the benefits, although primarily realised under projected future climate change, may be relatively large. These measures usually require an initial investment.

These strategies allow users of the Adaptation Actions Tool to identify adaptation actions that are in line with resource and capacity availability. In cases where a local authority has no or very limited additional resources available for climate-change adaptation, they may take into account only win-win actions and consider integrating these into existing plans and projects.

\subsubsection{Linking adaptation actions}

From the review of literature and case studies, it seems that isolated adaptation actions are less likely to be effective. Municipalities should ideally, in collaboration with relevant role players, develop and compile a 'basket' of measures that is suitable to the context, taking into consideration its capacity and finances, and the local geography, topography, and population profile. For this reason, interrelated and mutually beneficial or supportive adaptation actions were identified and linked, using a matrix to create 'baskets' of actions that can be implemented together across scales, sectors, and systems. These 'baskets' of different adaptation actions support sustainable and integrated interventions to adapt settlements to climate change (Pieterse, Davis-Reddy \& Van Niekerk 2019a: 10-11).

\subsection{Applying the Adaptation Actions Tool}

The Green Book does not prioritise adaptation actions per settlement. It is the responsibility of each local municipality to select the most appropriate actions, given their local context and understanding, to be integrated into its local planning strategies and plans. Adaptation planning needs to be tailored to local and regional conditions, current and projected future climate risks, and local capacities. Some South African coastal cities, for example, have become industrial hubs with significant port operations that are vulnerable to the impacts of a rise in sea level and coastal storm surges, while some South African inland cities 
are commercial and financial hubs, with a legacy of mining, that are vulnerable to extreme weather events such as heatwaves, floods, and storms. South African cities also have a common socio-economic context within which vulnerable residential communities are often located in close proximity to industrial activities and other high-risk areas, thereby exacerbating risks posed by poor air quality and extreme weather events to human settlements. The adaptation response, therefore, needs to be customised per local municipality and settlement. Identifying and prioritising the appropriate adaptation actions for a specific settlement thus require a number of key considerations. Figure 10 proposes a framework for mainstreaming adaptation actions into local plans and instruments.

Step 1 (Figure 11) is to understand the local climate risk and vulnerability context. To understand what contributes to municipal and

household vulnerability, one needs to study the municipal risk profile in the Risk Profile Tool (see Le Roux et al., 2019c). For instance, whether it has a growing or declining population, what hazards it is exposed to, and how climate change will impact on local water resources, agriculture and other economic sectors in future. It is important to understand the uncertainty associated with climate-change projections.

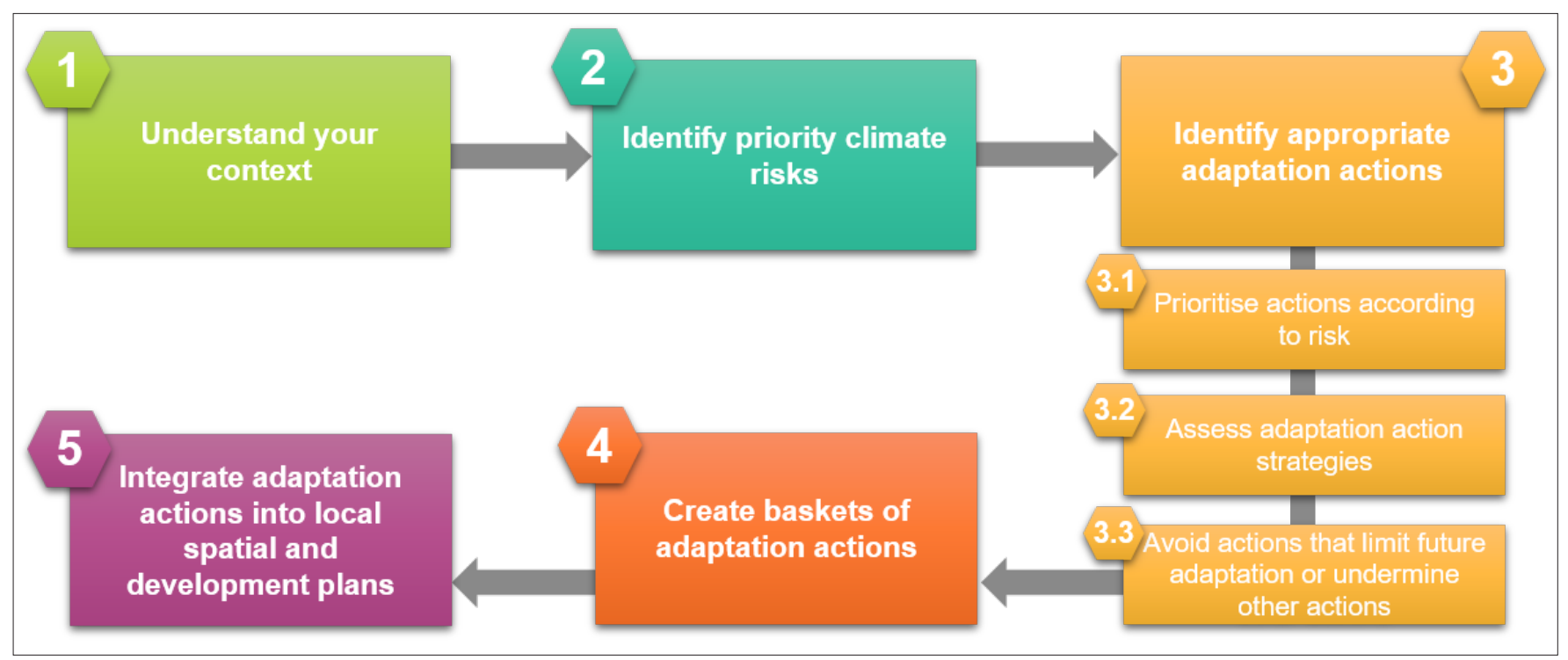

Figure 10: Mainstreaming climate change adaptation actions into plans

Source: $\quad$ Pieterse et al., 2019b: 5

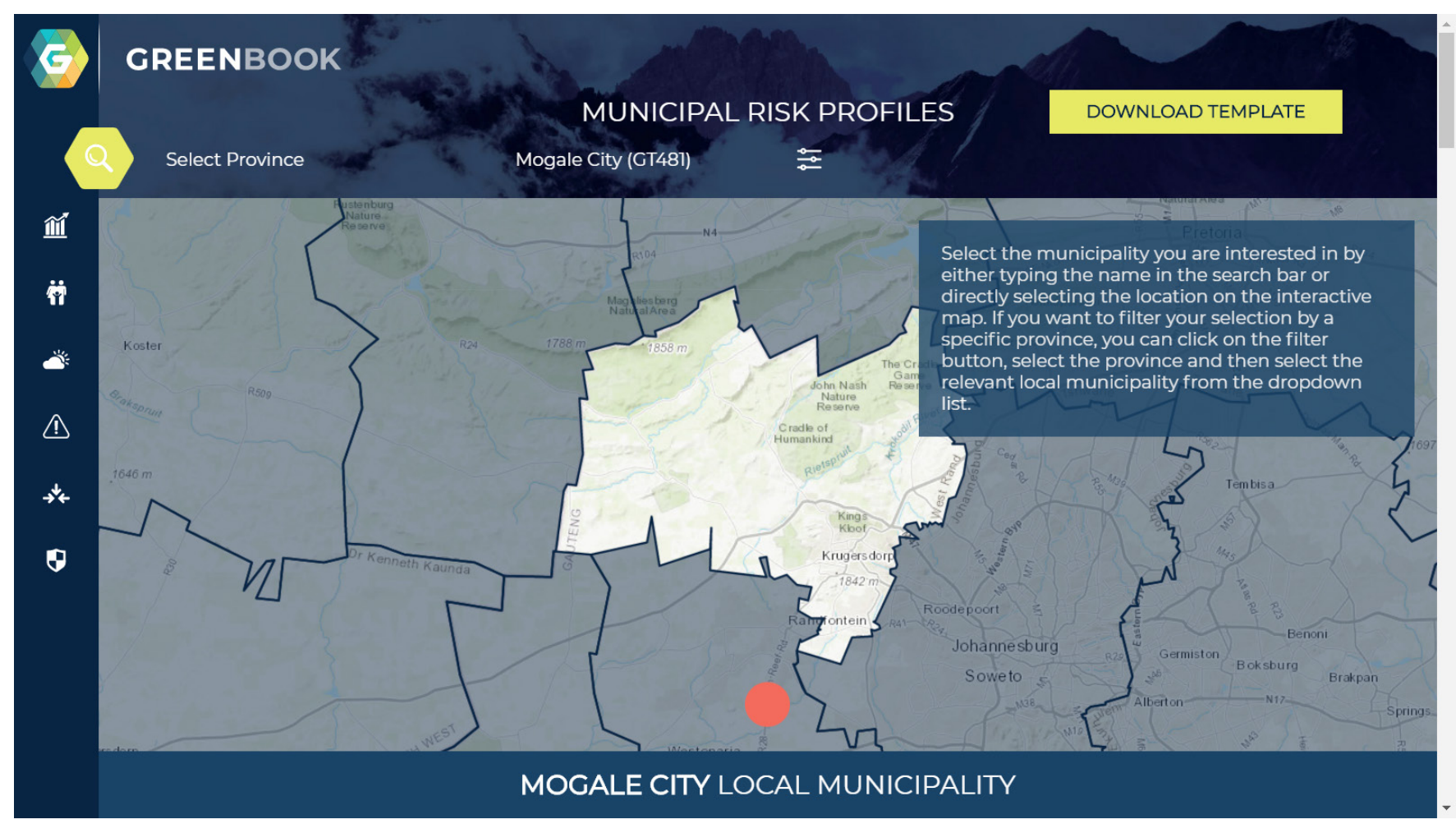

Figure 11: Step 1: Understand the local climate risk and vulnerability context

Source: Le Roux et al., 2019c: online 
Step 2 (Figure 12) is to identify priority climate risks. From the local risk profile, one needs to identify the climate hazards and impacts that pose the greatest risk. The hazards and impacts that pose a high and extreme risk to a municipality and its settlements are identified in the hazard risk maps.

Step 3 (Figures 13 and 14). Step 3.1 is to identify appropriate adaptation actions according to risk. Once the hazards and climate impacts that pose the greatest risk in a municipality have been identified, the adaptation actions that can reduce these risks can be selected in the Adaptation Actions Tool (Van Niekerk et al., 2019). One can filter the list of adaptation actions by the identified priority hazards and climate impacts.

Step 3.2 is to assess adaptation actions strategies. One would need to further prioritise the list of adaptation actions by assessing no-regret, low-regret and win-win actions in terms of their cost-effectiveness, the financial and human resource capacity available to implement these, and the multiple benefits or co-benefits these actions would have.

Step 3.3 is to avoid actions that limit future adaptation or undermine other actions. Adaptation actions that limit future adaptation to changing risks need to be avoided, as these can increase vulnerability or undermine future efforts to address climate change (i.e. maladaptation). Municipalities should also study the qualitative costs of the identified adaptation actions (under the description of each action) to understand the potential negative impacts or implications that specific adaptation actions may have on each other. Climate change adaptation outcomes and goals need to be weighed against one another to manage any conflict between actions.

Step 4 (Figure 14) is to create baskets of adaptation actions. One can combine actions with others to ensure short- and long-term adaptation outcomes. Mutually beneficial or supporting adaptation actions can be grouped together for implementation. Rarely will implementing one action sufficiently address a single or multiple risks. Adaptation actions need to be implemented alongside others that will support and reinforce them. For example, to address the risk of flooding, a municipality would need to "determine flood lines", "enforce flood lines" through land-use management, "visibly demarcate flood lines", as well as "maintain stormwater systems".

Step 5 is to integrate adaptation actions into local spatial and development plans. To ensure that adaptation actions are implemented, the risk is managed, and local resilience to climate change and its impacts are increased, climatechange adaptation needs to be integrated into local plans and projects. Climate-change adaptation actions should be included in dedicated climate-change response and disaster-management plans, but they should also form part of Integrated Development Planning (IDP), Spatial Development Framework (SDF), and Service Delivery and Budget Implementation Plan (SDBIP). By integrating climatechange adaptation into existing planning documents, processes and budgets, climate-response outcomes can be achieved while pursuing development outcomes. The adaptation actions in this tool have been designed to be integrated within local planning documents and processes, since they align with specific local government mandates and planning functions.

\section{CONCLUSION}

Local government plays a key role in climate-change adaptation, because successful responses depend on local policies, plans, and processes. Providing evidence and information to support climatechange adaptation in cities and towns, as well as mainstreaming climate-change adaptation into local government planning instruments and processes, is essential to support short- and long-term planning for sustainable development.
The Green Book is a first of its kind in the world. In a benchmarking exercise, no other adaptation planning support tools were found that combine adaptation actions with customised risk profiles per local municipality for the whole country. The specific focus on settlement planning is also novel. With the evidence and planning support provided by the Green Book, local municipalities (and those involved in local planning) are able to plan for current threats, and prioritise interventions to adapt settlements to future climatic changes through effective forward planning. The Green Book addresses the need by municipalities (and many indirect stakeholders) to understand their current vulnerabilities, likely future climatic changes and impacts on settlements, as well as how to adapt to these potential threats, in order to climate proof their settlements, reduce the exposure of people and places to the impact of hazards, and develop sustainably. The Green Book was conceptualised in response to these needs, to offer a resource to South African local government to better understand their risks and vulnerabilities in relation to population growth, climate change, and exposure to hazards, and the vulnerability of critical resources. It also provides appropriate adaptation measures that can be implemented in cities and towns, enabling South African settlements to minimise the impact of climate hazards on communities and infrastructure, while also contributing to developmental goals.

More research is required on the feasibility of the adaptation actions, specifically by evaluating the long-term effectiveness, cost and relevance of the adaptation actions in practice. The research team is also in the process of extending the adaptation actions to other city functions and linking these to specific climate-risk zones in the metropolitan cities. 


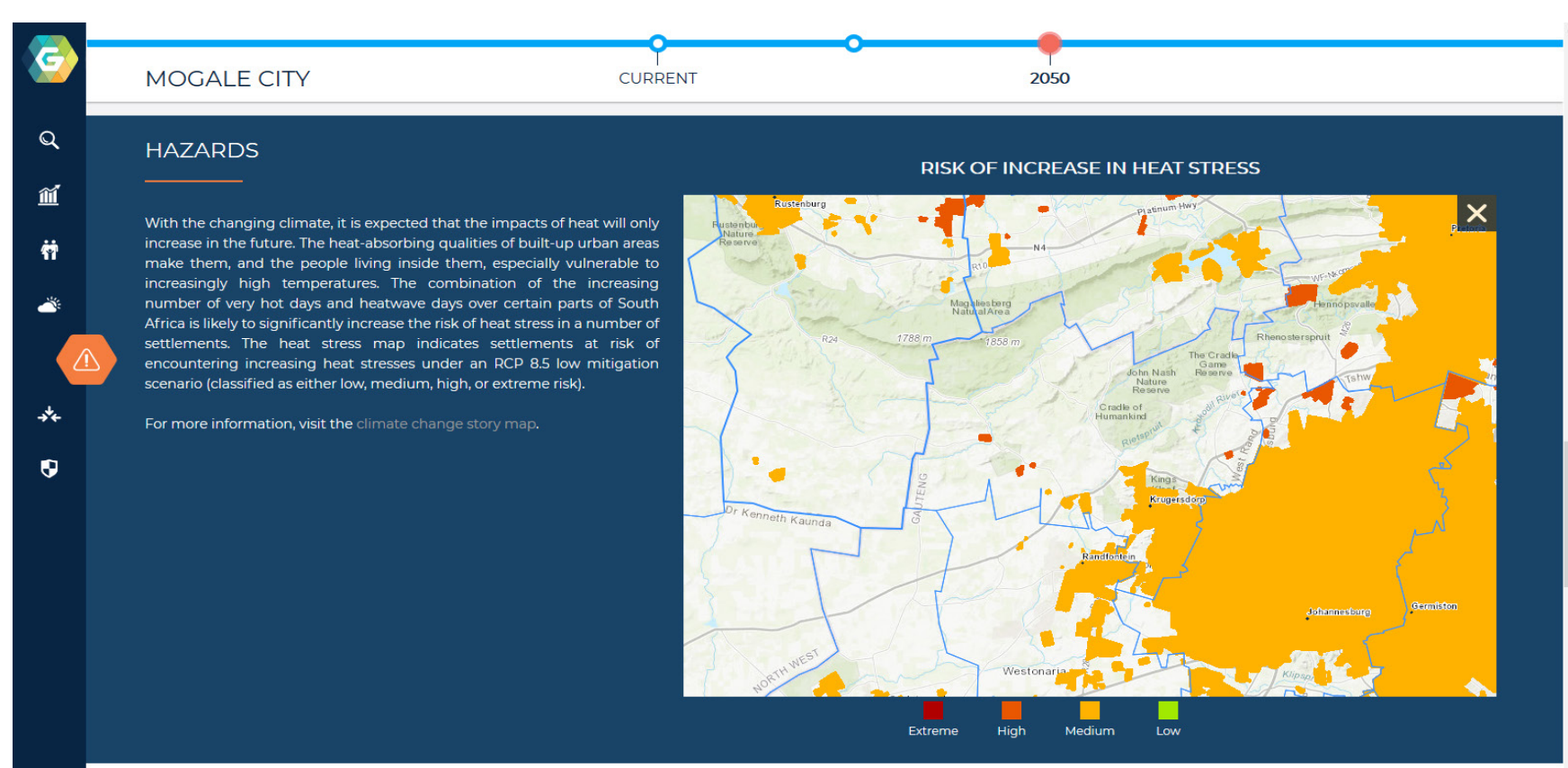

IMPACT OF CLIMATE CHANGE

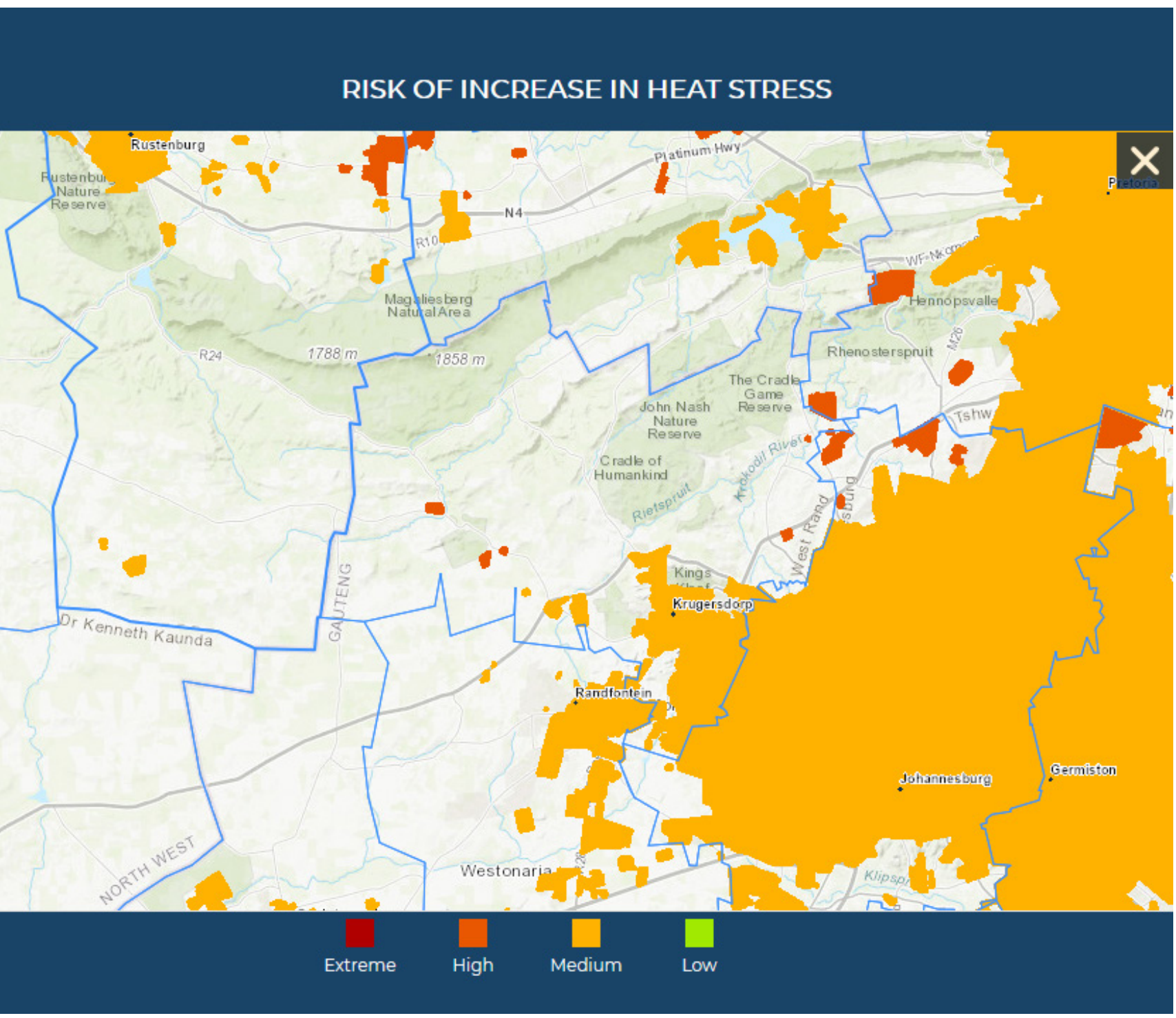

Figure 12: Identify the priority climate risks

Source: Le Roux et al., 2019c: online 


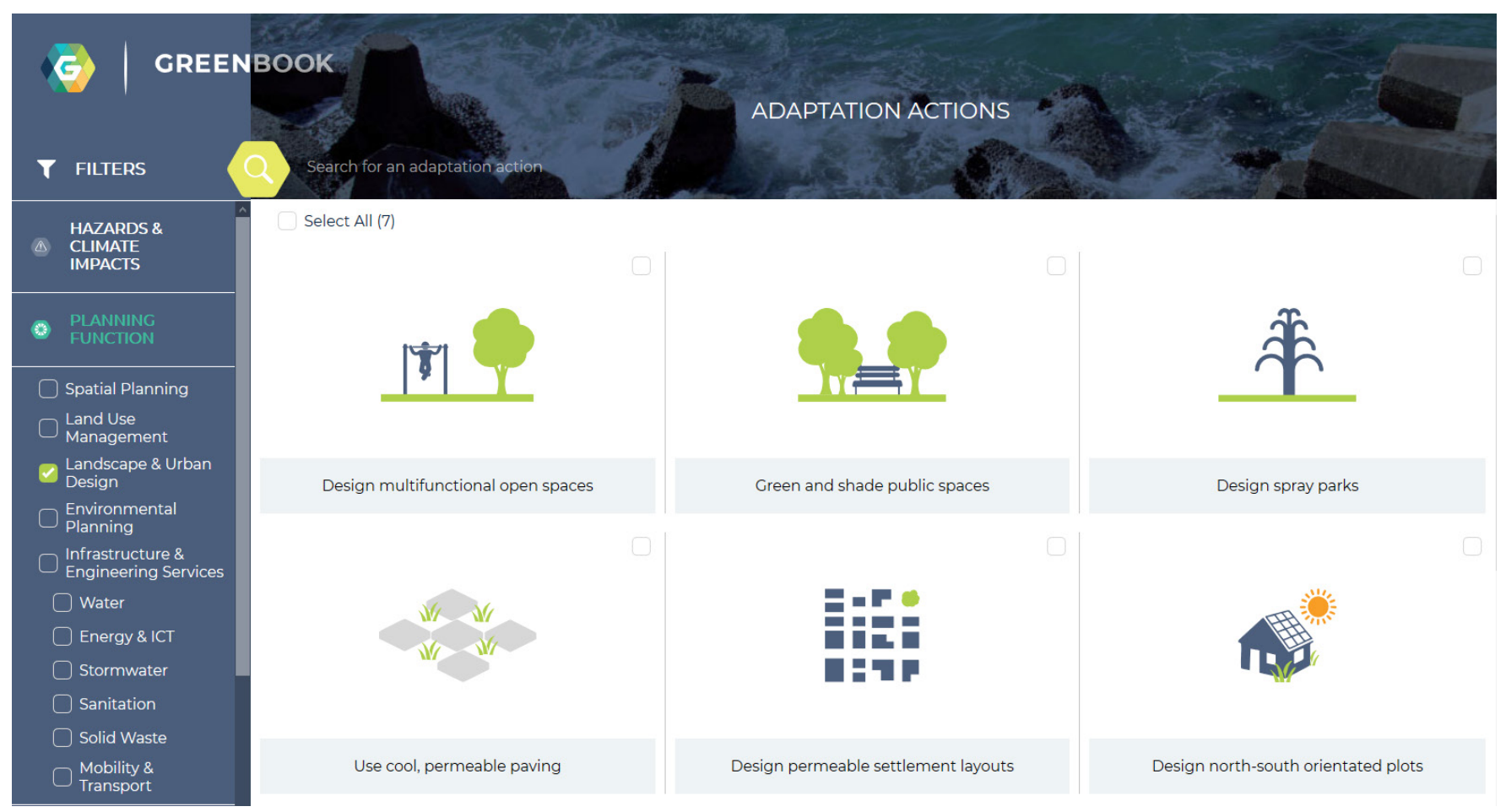

Figure 13: Step 3: Identify appropriate adaptation actions

Source: Van Niekerk et al., 2019b: online

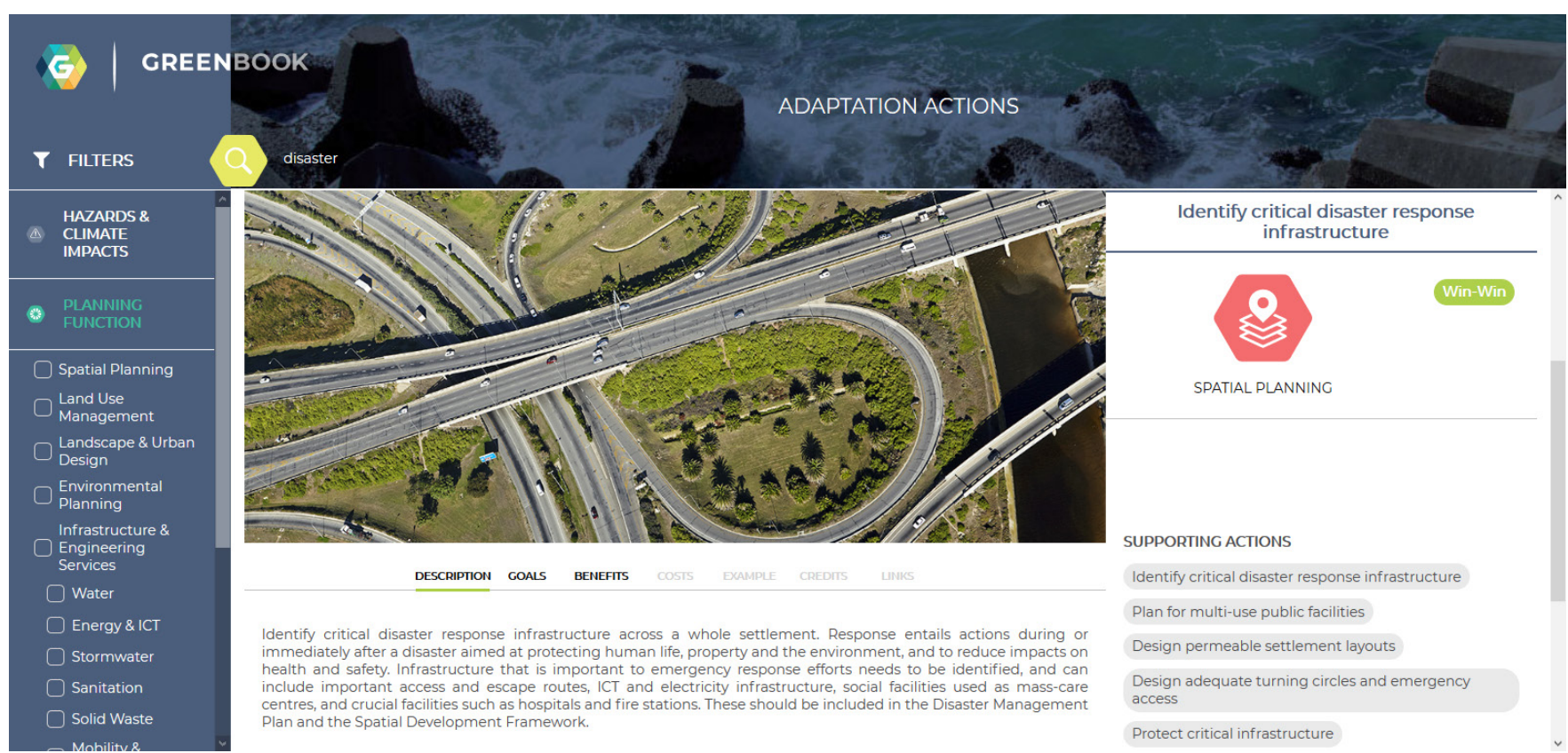

Figure 14: Step 3: Adaptation actions descriptions, including supporting actions

Source: Van Niekerk et al., 2019b: online

\section{ACKNOWLEDGEMENT}

The work was co-funded by the International Development Research Centre (IDRC) and the Council for Scientific and Industrial Research (CSIR).

\section{REFERENCES}

ANGUELOVSKI, I., CHU, E. \& CARMIN, J. 2014. Variations in approaches to urban climate adaptation: Experiences and experimentation from the global South. Global Environmental Change, vol. 27, pp. 156-167. https://doi. org/10.1016/j.gloenvcha.2014.05.010
BERAKI, A., LE ROUX, A. \& LUDICK, C. 2019. Green Book: The impact of climate change on drought. [Online]. Available at: <https://pta-gis-2-web1. csir.co.za/portal2/apps/GBCascade/ index.html?appid=42ef0ab1e90b4c 09b3f4e17cf0ab2550> [Accessed: 18 June 2020]. 
BIESBROEK, G., SWART, R. \& VAN

DER KNAAP, W. 2009. The mitigationadaptation dichotomy and the role of spatial planning. Habitat International, 33(3), pp. 230-237. https://doi. org/10.1016/j.habitatint.2008.10.001

CARMONA, M., BURGESS, R. \& BADENHORST, M. 2009. Planning through projects: Moving from master planning to strategic planning: 30 cities. Techne Press. [Online]. Available at: <http://www.technepress.nl/ publications. php?id=31> [Accessed: 18 June 2020].

CHEN, C., DOHERTY, M., COFFEE, J., WONG, T. \& HELLMANN, J. 2016. Measuring the adaptation gap: A framework for evaluating climate hazards and opportunities in urban areas. Environmental Science \& Policy, vol. 66, pp. 403-419. https://doi. org/10.1016/j.envsci.2016.05.007

CSIR (COUNCIL FOR SCIENTIFIC AND INDUSTRIAL RESEARCH). 2019. Green Book: Adapting South African settlements to climate change. [Online] Available at: <https://www.greenbook. co.za/index.html> [Accessed: 18 June 2020].

ENGELBRECHT, F., LE ROUX, A., ARNOLD, K. \& MALHERBE, J. 2019. Climate change. [Online]. Available at: <https://pta-gis-2-web1.csir.co.za/ portal2/apps/GBCascade/index.html?a ppid=700156e0242d4d0ea833cba8d0 2a4544> [Accessed: 18 June 2020].

FALING, W. 2010. Climate change and African cities. [Online]. Available at: $<$ https://www.africanplanningschools. org.za/resources/curriculumresources\#theme-2-climate-changeand-african-cities> [Accessed: 27 June 2020].

FORSYTH, G., LE MAITRE, D., LE ROUX, A. \& LUDICK, C. 2019. Green Book: The impact of climate change on wildfires in South Africa. [Online]. Available at: <https://pta-gis-2-web1. csir.co.za/portal2/apps/GBCascade/ index.html?appid=cf30c5ee571a4e 5f8509773325451cd3> [Accessed: 18 June 2020].

HAGEN, B. 2016. The role of planning in minimizing the negative impacts of global climate change. Urban Planning, 1(3), pp. 13-24. https://doi. org/10.17645/up.v1i3.671
IPCC (INTERGOVERNMENTAL PANEL ON CLIMATE CHANGE). 2014. Climate Change 2014: Synthesis Report. Contribution of Working Groups I, II and III to the Fifth Assessment Report of the Intergovernmental Panel on Climate Change (p. 151). Geneva, Switzerland: Intergovernmental Panel on Climate Change. [Online]. Available at: <https://www.ipcc.ch/report/ar5/syr/> [Accessed: 18 June 2020]. https://doi. org/10.1017/CBO9781107415416

IPCC (INTERGOVERNMENTAL PANEL ON CLIMATE CHANGE). 2018. Global Warming of $1.5^{\circ} \mathrm{C}$. Geneva, Switzerland: Intergovernmental Panel on Climate Change. [Online]. Available at: <https://www.ipcc.ch/sr15/ chapter/summary-for-policy-makers/> [Accessed: 4 December 2018].

KATES, R.W., TRAVIS, W.R.

\& WILBANKS, T.J. 2012.

Transformational adaptation when incremental adaptations to climate change are insufficient. Proceedings of the National Academy of Sciences, 109(19), pp. 7156-7161. https://doi. org/10.1073/pnas.1115521109

LE MAITRE, D., KOTZEE, I., LE ROUX, A. \& LUDICK, C. 2019. Green Book: The impact of climate change on flooding in South Africa. [Online]. Available at: <https://pta-gis-2-web1. csir.co.za/portal2/apps/GBCascade/ index. html?appid=3da8eefc440e47 cfbe43796a8ba5e64a> [Accessed: 18 June 2020].

LE ROUX, A., ARNOLD, K., MAKHANYA, S. \& MANS, G. 2019a. Our urban future. [Online] Available at: <https://pta-gis-2-web1.csir.co.za/ portal2/apps/GBCascade/index.html?a ppid=3c4901e8681244d1a7989e8ed2a ce1f9> [Accessed: 18 June 2020].

LE ROUX, A., VAN HUYSSTEEN, E., ARNOLD, K. \& LUDICK, C. 2019b. Green Book: The vulnerabilities of South Africa's settlements. [Online]. Available at: <https://pta-gis-2-web1. csir.co.za/portal2/apps/GBCascade/ index.html?appid=cbe48f255b9543 5fb12146f382a3ec6b> [Accessed: 26 June 2020].

LE ROUX, A., VAN NIEKERK, W., ARNOLD, K., PIETERSE, A., LUDICK, C., FORSYTH, G., LE MAITRE, D., LÖTTER, D., DU PLESSIS, P. \& MANS, G. 2019c. Green Book Risk Profile Tool. [Online]. Available at: <https://riskprofiles.greenbook.co.za/> [Accessed: 27 June 2020].
LONSDALE, K., PRINGLE, P. \& TURNER, B. 2015. Transformational adaptation: What it is, why it matters and what is needed. UK Climate Impacts Programme, University of Oxford, Oxford, UK. [Online]. Available at: <https://www.weadapt. org/knowledge-base/transforminggovernance/transformationaladaptation> [Accessed: 5 November 2019].

LÜCK-VOGEL, M., LE ROUX, A. \& LUDICK, C. 2019. Green Book: The impact of climate changes on coastal zones. [Online]. Available at: <https:// pta-gis-2-web1.csir.co.za/portal2/apps/ GBCascade/index.html?appid=167c 6e4cdd784527b5291b642ed73531> [Accessed: 18 June 2020].

PARNELL, S. 2016. Defining a global urban development agenda. World Development, vol. 78, pp. 529-540. https://doi.org/10.1016/j. worlddev.2015.10.028

PASQUINI, L. \& SHEARING, C. 2014. Municipalities, politics, and climate change: An example of the process of institutionalizing an environmental agenda within local government. The Journal of Environment \& Development, 23(2), pp. 271-296. https://doi. org/10.1177/1070496514525406

PELLING, M., O'BRIEN, K. \& MATYAS, D. 2015. Adaptation and transformation. Climatic Change, 133(1), pp. 113-127. https://doi.org/10.1007/ s10584-014-1303-0

PIETERSE, A., DAVIS-REDDY, C. \& VAN NIEKERK, W. 2019a. Developing a typology of climate change adaptation actions. Pretoria: CSIR Smart Places.

PIETERSE, A., DAVIS-REDDY, C. \& VAN NIEKERK, W. 2019b. Guidelines for the selection and prioritisation of adaptation actions. Pretoria: CSIR Smart Places.

PIETERSE, A., DU TOIT, J. \& VAN NIEKERK, W. 2020. Climate change adaptation mainstreaming in the planning instruments of two South African local municipalities. Development Southern Africa, https://doi.org/10.1080/037683 5X.2020.1760790

PIETERSE, A., VAN NIEKERK, W. \& DU TOIT, J. 2018. Creating resilient settlements through climate change adaptation planning. Presented at the Planning Africa Conference, 15-17 October, Cape Town, South Africa. 
PIETERSE, A., VAN HUYSSTEEN, E., VAN NIEKERK, W., LE ROUX, A., NAPIER, M., NDABA, D. \& MAHLELELA, S. 2016. Aligning and targeting spatial investment: Exploring assumptions, accomplishments and challenges. Unpublished report.

Pretoria: CSIR Built Environment.

RAUKEN, T., MYDSKE, P.K. \&

WINSVOLD, M. 2015. Mainstreaming climate change adaptation at the local level. Local Environment, 20(4), pp. 408-423. https://doi.org/10.1080/13549 839.2014.880412

REPUBLIC OF SOUTH AFRICA.

2013. Spatial Planning and Land Use Management Act, 16 of 2013. Pretoria: Government Printer.

VAN NIEKERK, W. 2013. Translating disaster resilience into spatial planning practice in South Africa: Challenges and champions. Jàmbá, 5(1), pp. 1-6. https://doi.org/10.4102/jamba.v5i1.53

VAN NIEKERK, W. \& LE ROUX, A.

2017. Human settlements. In: DavisReddy, C.L. \& Vincent, K. (Ed.). Climate risk and vulnerability: $A$ handbook for Southern Africa. $2^{\text {nd }}$ edition. Pretoria: CSIR, pp. 100-110.

VAN NIEKERK, W., PIETERSE, A., DAVIS-REDDY, C., LE ROUX, A. \& LÖTTER, D. 2019. Green Book Adaptation Actions Tool. [Online]. Available at: <https://adaptationactions. greenbook.co.za/> [Accessed: 27 June 2020].

WILSON, E. 2006. Adapting to climate change at the local level: The spatial planning response. Local Environment, 11(6), pp. 609-625. https://doi. org/10.1080/13549830600853635 